\title{
Rethinking Prior Restraint
}

\author{
John Calvin Jeffries, Jr. $\dagger$
}

Only once in the history of the Republic has the Supreme Court witnessed a head-on collision between national security and the First Amendment. The case was New York Times Co. v. United States, ${ }^{1}$ where the government sought to enjoin publication of classified documents known as the Pentagon Papers. The issue, said the per curiam opinion for the Court, was one of "prior restraint": "Any system of prior restraints of expression comes to this Court bearing a heavy presumption against its constitutional validity."2 The government therefore faced "a heavy burden of showing justification for the imposition of such a restraint,"s and its failure to carry that burden meant the denial of injunctive relief.

This sort of talk flows easily from the rhetorical tradition of the First Amendment, but in fact the significance of focusing on prior restraint was not all that clear. New York Times was litigated in pell-mell haste, and a hurried majority assembled behind a conclusory per curiam. Separate concurrences revealed an underlying diversity of opinion. For Justices Black and Douglas, the Pentagon Papers dispute called for the reaffirmation of an absolute commitment to an unfettered press. Their view of the case did not turn on the form or timing of government intervention, but on a more basic refusal to countenance "[t] secrets at the expense of informed representative government." Justice Brennan dwelt more on the posture of the case as a request for injunctive relief, but without explaining why that should matter. On the merits, Brennan came close to Justice Black. He admitted the possibility of valid prior restraints in "a single, extremely narrow class of cases," but defined that class so strictly that he approached the absolutist position: "[O]nly governmental allegation and proof that publication must inevitably, directly, and immediately cause the occurrence of an event kindred to imperiling the safety of a transport already at sea can support even the issu-

\footnotetext{
+ Professor of Law, University of Virginia. This paper was first presented to the January, 1982, Conference on the First Amendment and National Security sponsored by the Center for Law and National Security at the University of Virginia School of Law. I am indebted to the Center's Director, John Norton Moore, for his support and to participants in the Conference for criticism and suggestions. Further thanks go to Lillian BeVier, Peter Low, Robert Scott, and Paul Stephan for reading and commenting on a subsequent draft. The views expressed herein are, of course, entirely my own.

1. 403 U.S. 713 (1971) (per curiam).

2. Id. at 714 (quoting Bantam Books, Inc. v. Sullivan, 372 U.S. 58, 70 (1963)).

3. Id. (quoting Organization for a Better Austin v. Keefe, 402 U.S. 415, 419 (1971)).

4. Id. at 719 (Black, J., with whom Douglas, J., joined, concurring).
} 
ance of an interim restraining order." Justice Marshall, in contrast, elided discussion of the First Amendment in favor of a focus on separation of powers. He found it critical that Congress had not authorized suits to enjoin publication of security secrets. For Marshall, therefore, the defect in the request for an injunction lay not so much in the status of prior restraints under the First Amendment as in the limited powers of the coordinate branches in the face of specific legislative refusal to authorize such proceedings. ${ }^{6}$

For two members of the majority, however, the specially disfavored status of prior restraints under the First Amendment seems to have been the actual stuff of decision, and not merely a convenient point of rhetoric. Writing for himself and for Justice Stewart, Justice White announced that his vote rested on "the concededly extraordinary protection against prior restraints enjoyed by the press under our constitutional system." asserted a constitutional distinction between prior restraint and subsequent punishment and suggested that the government may simply have tried the wrong door:

Prior restraints require an unusually heavy justification under the First Amendment; but failure by the Government to justify prior restraints does not measure its constitutional entitlement to a conviction for criminal publication. That the Government mistakenly chose to proceed by injunction does not mean that it could not successfully proceed in another way. ${ }^{8}$

White sharpened his point by referring to provisions of the Espionage $\mathrm{Act}^{9}$ and noted that he "would have no difficulty in sustaining convictions under these sections on facts that would not justify the intervention of equity and the imposition of a prior restraint."

Justice White's opinion illustrates the operative significance of the doctrine of prior restraint. The doctrine imposes a special disability on official attempts to suppress speech in advance of publication-a disability that is independent of the scope of constitutional protection against punishment subsequent to publication. In other words, speech that validly could be controlled by subsequent punishment nevertheless would be immune from regulation by prior restraint. As Professor Emerson put it, "the doctrine

5. Id. at 726-27 (Brennan, J., concurring).

6. Id. at 742-47 (Marshall, J., concurring). Justice Marshall recounted two instances of Congressional inaction and characterized the case as one where "the Executive Branch comes to this Court and asks that it be granted the power Congress refused to give." Id. at 747.

7. Id. at 730-31 (White, J., with whom Stewart, J., joined, concurring).

8. Id. at 733 .

9. Id. at $735-40$ (discussing 18 U.S.C. $\S \S 793(\mathrm{e}), 797,798$ (1970)).

10. 403 U.S. at 737. 
deals with limitations of form rather than of substance."11

It follows, therefore, that the doctrine must be justified by considerations dependent on form and not simply by reference to the substantive coverage of the First Amendment. Any instance of speech or expression that would be protected from subsequent punishment is a fortiori secured against prior restraint, ${ }^{12}$ and therefore reveals nothing of the independent effect ascribed to that doctrine. Where the speech in question is in all events guaranteed by the First Amendment, attributing that guarantee to the circumstance of prior restraint is at best irrelevant and often misleading. The testing case is, rather, one in which speech is concededly (or at least arguably) outside the substantive protection of the First Amendment but assertedly within the ban of prior restraints. The position of Justices White and Stewart in New York Times Co. v. United States presents just such a case.

My purpose here is to examine the doctrine of prior restraint and to ask what, if any, role it should play in modern adjudication of the First Amendment. ${ }^{13}$ The White-Stewart position in New York Times is a suitable starting point, both because it presents an analytically clear case of the doctrine at work and because it depicts that doctrine against the background of a professed concern for national security. Focusing on a claim of national security seems to me apt because it is precisely (though not

11. Emerson, The Doctrine of Prior Restraint, 20 LAW \& CONTEMP. ProBS. 648, 648 (1955).

12. Nebraska Press Ass'n v. Stuart, 427 U.S. 539, 598 (1976) (Brennan, J., concurring in judgment) ("Prior restraints are particularly anathematic to the First Amendment, and any immunity from punishment subsequent to publication of given material applies a fortiori to immunity from suppression of that material before publication.").

13. This is a convenient place to acknowledge my indebtedness to the substantial tradition of scholarship on the doctrine of prior restraint. The classic treaiment is Emerson, supra note 11. Emerson wrote to uphold the basic soundness of the rule against prior restraint, and he developed that position with unequaled force and sophistication. His arguments are, therefore, a frequent point of departure in the pages that follow.

Emerson wrote, at least in part, in response to earlier criticisms of the prior restraint doctrine. Best known and still useful are the few pages on this subject in Freund, The Supreme Court and Civil Liberties, 4 VAND. L. REV. 533, 537-39, 541-45 (1951). See also Note, Prior Restraint-A Test of Invalidity in Free Speech Cases?, 49 COLUM. L. REV. 1001 (1949) (questioning usefulness of prior restraint doctrine).

Of special note among the legion of more modern treatments of prior restraint are: Barnett, The Puzzle of Prior Restraint, 29 STAN. L. REV. 539 (1977), which was published as part of a symposium on Nebraska Press Ass'n v. Stuart but which also includes insightful remarks on the application of the prior restraint doctrine outside that context; Mayton, Toward a Theory of First Amendment Process: Injunctions of Speech, Subsequent Punishment, and the Costs of the Prior Restraint Doctrine, 67 CORNell L. REV. 245 (1982); Murphy, The Prior Restraint Doctrine in the Supreme Court: A Recvaluation, 51 NOTRE DAME LAW. 898 (1976); and the excellent discussion of this issue in Schauer, Fear, Risk and the First Amendment: Unraveling the "Chilling Effect", 58 B.U.L. REV. $685,725-31$ (1978).

Finally, special mention should be made of Blasi, Toward a Theory of Prior Restraint: The Central Linkage, 66 MINN. L. REV. 11 (1981), which provides the most comprehensive and detailed treatment of this subject since Emerson. Professor Blasi's important article appeared after the initial draft of this paper, but aspects of his argument are discussed infra notes 57, 67. 
exclusively) in that context that the government is likely to assert a strong justification for imposing prior restraint. Even a weak or highly speculative explanation for the rule of special hostility to prior restraint may well seem persuasive where the government has no good reason to proceed in that manner. So it is, for example, in the regulation of obscenity. Whatever harm may be thought to flow from the publication of pornography presumably varies directly with the incidence of distribution. The societal cost of showing a dirty movie several times is likely to be some multiple of the harm of showing it once. The case for the government to seek suppression by prior restraint rather than by subsequent punishment is, therefore, not particularly strong, and little would seem to be lost in denying that opportunity. ${ }^{14}$ In the field of national security, by contrast, virginity matters. The harm that may be expected to flow from revealing a state secret is almost exclusively related to the first publication. Accordingly, the government's interest in acting before publication is greater, and the rationale for a rule of special hostility to this form of regulation is put more sharply in issue.

The history of the doctrine of prior restraint has been recounted elsewhere, ${ }^{15}$ and need not be fully related here. Most accounts begin with the English Licensing Act of 1662 and its scheme of official licensing for all printed publications. The Licensing Act was allowed to expire in 1694, apparently not so much from opposition to the principle of the statute as from frustration with the absurdities and inequities of its administration. As Emerson said, the licensing system had become "unwieldy, extreme, and even ridiculous." ${ }^{16}$ A century later, however, freedom from licensing of the press had come to be seen as one of the rights of Englishmen. Hence, the famous passage in which Blackstone equated freedom of the press with a rule against prior restraint:

14. That is not to say, of course, that there may not be other reasons for accepting, or even preferring, a regime of prior restraint, but only that the government's interest in this particular mode of regulation is not especially weighty. One could argue, for example, that individual liberty is enhanced if government regulation of obscenity is accomplished by prior restraint, with advance determination of what is proscribed, rather than by reliance on the admonitory message of penal statutes, which are inevitably vague in identifying what is and what is not "obscene." See Ginsberg v. New York, 390 U.S. 629 (1968).

In fact, however, the Supreme Court has held that obscenity is not protected speech, Roth v. United States, 354 U.S. 476 (1957), and may be subject to prior restraint in limited circumstances, see Freedman v. Maryland, 380 U.S. 51 (1965); infra p. 424 (discussing Freedman). 49.

15. See Emerson, supra note 11, at 650-52 (sources cited therein); Mayton, supra note 13, at 247 -

16. Emerson, supra note 11, at 651. 


\section{Prior Restraint}

The liberty of the press is indeed essential to the nature of a free state; but this consists in laying no previous restraints upon publications, and not in freedom from censure for criminal matter when published. Every freeman has an undoubted right to lay what sentiments he pleases before the public; to forbid this is to destroy the freedom of the press, but if he publishes what is improper, mischievous, or illegal, he must take the consequence of his own temerity. ${ }^{17}$

Two distinct propositions are conjoined in Blackstone's statement, and later generations have emphasized first one and then the other aspect of his pronouncement. For a long time, the chief import of Blackstone's position lay in what was not protected-namely, any "improper, mischievous, or illegal" speech or publication. In Blackstone's view, any such speech could validly be made subject to criminal prosecution. Adopted as a construction of the First Amendment, this view would have imposed little or no substantive limit on governmental authority to suppress speech, so long as such suppression was done by subsequent punishment and not by prior restraint. This idea (which strikes the contemporary student of the First Amendment as a relic from another world) enjoyed such currency that as late as 1941, Zechariah Chafee thought it necessary for "[ $t]$ his Blackstonian theory . . . to be knocked on the head once [and] for all'18 and spent several good pages delivering the coup de grâce. More modern observers usually look to the protective aspect of Blackstone's statement. They commonly cite him to confirm the doctrine of prior restraint as an independent bar to official regulation of speech, one applicable even to speech not otherwise protected under the First Amendment.

One may well doubt whether sound guidance may be drawn from either half of Blackstone's bifurcation, or, indeed, whether any rendition of English law of the eighteenth century should be given special weight in contemporary interpretation of the First Amendment. In fact, however, the themes struck in Blackstone's passage on prior restraint recur throughout the later development of the doctrine and continue to shape our habits of thought on the subject. At least two legacies are apparent. First, the doubtful pedigree of First Amendment protection against subsequent punishment created a powerful incentive for advocates of expanded constitutional protection (and for judges who wished to vindicate such claims) to describe the restriction at hand as a prior restraint. This characterization was repeatedly urged and not infrequently adopted for matters surprisingly dissimilar from the English scheme of official licensing. In time, exploitation of the latent plasticities of "prior restraint" became a

17. 4 W. BLACKSTONE, COMMENTARIES * 152 .

18. Z. CHAFEE, FREE SPEECH IN THE UNITED STATES 9 (1941). 
familiar tactical short-cut to expanded substantive coverage of the First Amendment. Second, Blackstone founded the still vigorous tradition that speech should be more protected against prior restraint than against subsequent punishment. And this insistence has been reiterated without regard to whether "more protected" meant "more than not at all" or "more than a great deal." In a century in which each generation finds its predecessor's construction of the First Amendment insupportably narrow, the historic association of the doctrine of prior restraint with the more protective position has proved a potent source of prestige and authority. To put the point very roughly, a special bar against prior restraint has come increasingly to be viewed as a good thing, even as the notion of what constitutes a prior restraint has grown progressively more elastic and unstable.

These themes are evident in Near v. Minnesota, ${ }^{19}$ the Supreme Court's first great encounter with prior restraint, and the subsequent emergence of that case as the doctrine's leading precedent. Near involved a very odd statute. It authorized, under the law of public nuisance, judicial abatement of any newspaper or other periodical deemed "malicious, scandalous and defamatory." $\mathrm{mo}$ A defense was provided where the material complained of was both true and published "with good motives and for justifiable ends." 21 An action was brought under these provisions against a Minneapolis weekly devoted to exposing the alleged wrongdoings of Jewish gangsters and the accompanying corruption of city officials. In addition to ranting about Jews generally, the paper made charges of graft, neglect, and incompetence against the mayor, the chief of police, a special law enforcement official, and the county attorney. On complaint by the last of these figures, a state court adjudged the newspaper "malicious, scandalous and defamatory" and issued a perpetual injunction against any further publication of that description. The statute authorizing this injunction was challenged as invalid on its face, and in this posture the issue reached the Supreme Court. ${ }^{22}$

The Court struck down the law as an invalid prior restraint. "In determining the extent of the constitutional protection [of liberty of the press]," said Chief Justice Hughes, "it has been generally, if not universally, considered that it is the chief purpose of the guaranty to prevent previous restraints upon publication." ${ }^{23} \mathrm{He}$ then quoted Blackstone and others in condemnation of prior restraint. Hughes took pains to say that the bar

19. 283 U. S. 697 (1931). A careful unpacking of the Near decision may be found in Blasi, supra note 13 , at $151-59$.

20. 283 U.S. at 701.

21. Id. at 702 .

22. Id. at 703-07.

23. Id. at 713. 
against prior restraint was not absolute, ${ }^{24}$ nor was the constitutional protection against subsequent punishment entirely nonexistent. For the Court, however, there was plainly a constitutional difference between the two approaches, and Hughes rested the decision squarely on that ground:

In the present case, we have no occasion to inquire as to the permissible scope of subsequent punishment. For whatever wrong the appellant has committed or may commit, by his publications, the State appropriately affords both public and private redress by its libel laws. As has been noted, the statute in question does not deal with punishments; it provides for no punishment, except in case of contempt for violation of the court's order, but for suppression and injunction, that is, for restraint upon publication. ${ }^{25}$

\section{And again:}

The fact that the liberty of the press may be abused by miscreant purveyors of scandal does not make any the less necessary the immunity of the press from previous restraint in dealing with official misconduct. Subsequent punishment for such abuses as may exist is the appropriate remedy, consistent with constitutional privilege. ${ }^{28}$

Writing for himself and three other dissenters, Justice Butler disputed the characterization of the statute as a prior restraint. He reviewed Blackstone and the history of official licensing to which that authority had reference, and concluded:

The Minnesota statute does not operate as a previous restraint on publication within the proper meaning of that phrase. It does not authorize administrative control in advance such as was formerly exercised by the licensers and censors but prescribes a remedy to be enforced by a suit in equity. In this case there was previous publication made in the course of business of regularly producing malicious, scandalous and defamatory periodicals. The business and publications unquestionably constitute an abuse of the right of free press. The statute denounces the things done as a nuisance on the ground, as stated by the state supreme court, that they threaten morals, peace and good order. There is no question of the power of the State to denounce such transgressions. The restraint authorized is only in re-

24. One of the specified exceptions to the rule against prior restraint was destined to become particularly famous: "No one would question but that a government might prevent actual obstruction to its recruiting service or the publication of the sailing dates of transports or the number and location of troops." Id. at 716. Interestingly, the exceptions are not limited to matters of such dire consequence but also include, for example, the control of obscenity.

25. Id. at 715 .

26. Id. at 720 . 
spect of continuing to do what has been duly adjudged to constitute a nuisance . . . . ${ }^{27}$

As has been noted, Near illustrates several aspects of the developing doctrine of prior restraint. Most important is the assumption that terming the statute a prior restraint was doctrinally necessary to its invalidation. The dissent makes the point explicit. For the majority as well, the implicit assumption seems to have been that unless the law could be treated as a prior restraint, thus falling within the protective part of Blackstone's bifurcation, no settled or familiar basis would exist for holding the statute unconstitutional. And the statute had to be held unconstitutional. Otherwise, it could become a successful prototype for official suppression of hostile comment-at least of criticism sufficiently intemperate to be called "malicious, scandalous and defamatory." In truth, Near v. Minnesota involved nothing more or less than a repackaged version of the law of seditious libel, and this the majority rightly refused to countenance. Hence, there was pressure, so typical of this doctrine, to cram the law into the disfavored category of prior restraint, even though it in fact functioned very differently from a scheme of official licensing. Here there was no license and no censor, no ex parte determination of what was prohibited, and no suppression of publication based on speculation about what somebody might say. Here the decision to suppress was made by a judge (not a bureaucrat), after adversarial (not ex parte) proceedings, to determine the legal character of what had been (and not what might be) published. The only aspect of prior restraint was the incidental fact that the defendants were commanded not to repeat that which they were proved to have done.

The real defect, of course, was the substantive standard for authorizing suppression. The standard of "malicious, scandalous and defamatory" publication that is neither true nor published "with good motives and for justifiable ends" is utterly inconsistent with the fundamental First Amendment principle of free and unfettered political debate. ${ }^{28}$ And that inconsistency would persist, and would be equally intolerable, whether the suppression were accomplished by injunction or by criminal prosecution and punishment. The flaw lies in the standard for suppression, not in the form of the proceeding.

Now, one may well wonder whether this carping about categorization is

27. Id. at 735 (Butler, J., dissenting).

28. See New York Times Co. v. Sullivan, 376 U.S. 254, 270 (1964), where the Court voiced "a profound national commitment to the principle that debate on public issues should be uninhibited, robust, and wide-open, and that it may well include vehement, caustic, and sometimes unpleasantly sharp attacks on government and public officials." Note that this assertion was made not in the context of prior restraint but in consideration of a scheme of subsequent proceedings under the law of libel-precisely the alternative on which the Near Court suggested Minnesota should rely. 


\section{Prior Restraint}

not a bit off point. After all, if the Near Court reached the right result, does it really matter that it gave the wrong reason? The answer, I think, is that it does matter, at least that it has come to matter as Near has become a prominent feature of the First Amendment landscape-a landmark, as the case is so often called, from which we chart our course to future decisions. And the course indicated by Near is not simply to reject the law of seditious libel, whatever the mechanism of enforcement. Today, at least, that message would be everywhere accepted. Instead, Near has come to stand for a sort of syllogism about injunctive relief:

Prior restraint of speech is presumptively unconstitutional, even where the speech in question is not otherwise protected.

An injunction is a prior restraint.

Therefore, an injunction against speech is presumptively unconstitutional, even where the speech enjoined is not otherwise protected.

The White-Stewart position in New York Times is perfectly illustrative. And despite the continued reliance on this analysis in matters of no little consequence, the Court has yet to explain (at least in terms that I understand) what it is about an injunction that justifies this independent rule of constitutional disfavor.

The subsequent history of prior restraint may be stated summarily, for the later cases, although numerous, do little more than repeat and extend the developments already noted. The most established and coherent line of cases harks back to the original meaning of prior restraint as official licensing. ${ }^{29}$ In an impressive array of early decisions, the Supreme Court invoked the historic hostility to press licensing to invalidate modern permit requirements. In each of these cases, the instrument of enforcement was criminal prosecution and punishment. Prior restraint was imposed by conditioning the right to speak on advance approval by a government official. A violation of the law would be shown by proof of failure to obtain the required permit, regardless of whether that permit could constitutionally have been withheld. In other words, these statutes made the legality of

29. See, e.g., Joseph Burstyn, Inc. v. Wilson, 343 U.S. 495 (1952) (holding unconstitutional statute prohibiting unlicensed commercial screening of motion pictures and authorizing denial of license for any sacrilegious film); Kunz v. New York, 340 U.S. 290 (1951) (invalidating permit requirement for public worship on city streets); Niemotko v. Maryland, 340 U.S. 268 (1951) (overturning disorderly conduct conviction for holding religious meeting without permission of park commission); Saia v. New York, 334 U.S. 558 (1948) (striking down ordinance against use of sound amplification equipment not approved by police chief); Cantwell v. Connecticut, 310 U.S. 296 (1940) (voiding licensing requirement for religious solicitation); Lovell v. City of Griffin, 303 U.S. 444 (1938) (striking down municipal ordinance forbidding distribution of "literature of any kind" without prior permission of city manager). 
speech depend not on the substantive standard of exclusion from the First Amendment (for example, incitement or obscenity), but on the presence or absence of prior permission. Under such schemes, an executive official was empowered to determine, on the basis of ex parte consideration, whether speech should be permitted or suppressed. And, at least where the statutory authorization of such preclearance was not facially invalid, that determination would be binding and enforceable unless and until the wouldbe speaker obtained a contrary judicial declaration. ${ }^{30}$

Another line of cases picks up the innovation of Near v. Minnesota and extends the rule against prior restraint to a wide variety of injunctions against speech and publication. New York Times Co. v. United States is the premier example. Other well known cases are collected in the margin. ${ }^{31}$ In all of these cases, the Court found that the special bar against prior restraint was triggered by issuance of an injunction. In none of them, however, was it clear that the speech in question could validly have been suppressed by subsequent punishment. It is difficult to tell, therefore, whether the doctrine of prior restraint was merely a convenient rhetoric, or whether it was actually applied to protect against injunction speech that would not have been protected against prosecution and punishment. In either event, it seems clear that the mechanism of suppression in the use of injunctions bears little resemblance to that involved in the permit cases.

Finally, the rule against prior restraints has been invoked in a number of situations involving neither permit requirements nor injunctions. These situations are not only unlike both of the established patterns of prior restraint; they are also quite unlike one another. Three cases suffice to illustrate the point. Grosjean v. American Press $\mathrm{Co}^{32}$ treated as a prior restraint a gross receipts tax on newspapers. Bantam Books, Inc. v. Sullivan $^{33}$ invoked the same doctrine to strike down the Rhode Island Commission to Encourage Morality in Youth. That body operated as an informal censor by identifying certain books and magazines as objectionable for sale to minors. The Commission, however, had no authority to suppress such publications; it could only recommend criminal prosecution. The statute nevertheless was found to erect a system of prior restraint. And whatever

30. See Poulos v. New Hampshire, 345 U.S. 395, 409 (1953) (refusal to issue license for use of public park for religious services must be challenged through appropriate judicial process).

31. E.g., Oklahoma Publishing Co. v. District Court, 430 U.S. 308 (1977) (setting aside pretrial order enjoining publication of name or photograph of 11 -year-old boy charged with delinquency by murder); Nebraska Press Ass'n v. Stuart, 427 U.S. 539 (1976) (invalidating order against publication of confessions or other highly incriminating information until impaneling of jury in controversial murder prosecution); Organization for a Better Austin v. Keefe, 402 U.S. 415 (1971) (invalidating order prohibiting as invasion of privacy distribution of certain leaflets by citizens' organization).

32. 297 U.S. 233 (1936).

33. 372 U.S. 58 (1963). 
was the common thread linking Grosjean to Bantam Books, it was also found in Southeastern Promotions, Ltd. v. Conrad ${ }^{34}$ to apply to a city's refusal to rent a municipal theater for a production of "Hair."35

It is worth noting that this demonstration of vagary is taken exclusively from decisions of the Supreme Court of the United States. Attention to the pronouncements of lower federal courts, state courts, and academic commentators would dramatically reinforce the impression of elasticity and incoherence in the term "prior restraint." Perhaps the ultimate in both is reached by a Note insisting that "any system of prior restraint would be a greater deterrent to free expression than would a system of subsequent prohibitions," while at the same time describing the threat of subsequent punishment as "the most effective form" of prior restraint. ${ }^{36}$

\section{II.}

Even this abbreviated historical review should make plain the essential objection to the doctrine of prior restraint. At least as applied by the courts, the doctrine is fundamentally unintelligible. It purports to assess the constitutionality of government action by distinguishing prior restraint from subsequent punishment, but provides no coherent basis for making that categorization. In 1955, Professor Emerson said: "There is, at present, no common understanding as to what constitutes 'prior restraint." "37 The intervening years have only reinforced that observation. Some prior restraints involve permit requirements; others do not. Some involve injunctions; others do not. Some cases involving neither permits nor injunctions are treated as prior restraints; others are not. The doctrine purports to deal with matters of form rather than of substance, but there is no unity among the forms of government action condemned as prior restraints.

The explanation for this disarray lies in the historic association of

34. 420 U.S. 546 (1975).

35. For further examples in the same vein, see Smith v. Daily Mail Publishing Co., 443 U.S. 97 (1979); Young v. American Mini Theatres, Inc., 427 U.S. 50, 84 (1976) (Stewart, J., dissenting). In Smith, both petitioner and respondent agreed in characterizing as a prior restraint a penal statute barring publication of the names of juvenile offenders. The basis for this characterization was apparently that the statute included an exception allowing such publication with the permission of the juvenile court. In American Mini Theatres, Justice Stewart, in a dissent joined by Justices Brennan, Marshall, and Blackmun, applied the "prior restraint" characterization to a Detroit zoning ordinance restricting the permissible concentration of "adult" movie theatres. Whatever one may think of the merits of these two cases, the regulations at issue bear no obvious structural similarity either to permit requirements or to injunctions.

36. With apologies to Note, Prior Restraint and the Press Following the Pentagon Papers Cases-Is the Immunity Dissolving?, 47 NOTRE DAME LAW. 927, 930-32 (1972).

37. Emerson, supra note 11 , at 655 . In a similar vein, Harry Kalven once remarked that he thought it "not altogether clear just what a prior restraint is or just what is the matter with it." Kalven, The Supreme Court: 1970 Term-Foreword: Even When a Nation Is at War, 85 HARV. L. REV. 3, 32 (1971). 
"prior restraint" with a declaration of constitutional invalidity and in the consequent impetus to distort doctrine in order to expand protection. ${ }^{38}$ Today, such indirection is unnecessary. There is nothing left of the "Blackstonian theory" that the government may do what it will so long as it avoids prior restraint, and hence there is no need to invoke that categorization in order to protect First Amendment freedoms. We are left, therefore, with a doctrine of honored past but contemporary irrelevance-a formulation whose current contribution to the interpretation of the First Amendment is chiefly confusion.

The lack of settled content in the term "prior restraint" is, by now, painfully obvious, and might well be glossed over were it not for the surprising persistence of assumptions to the contrary. Despite long experience with the uncertainties of the term and admonitions from Emerson and others of the need for more precise definition, there is no shortage of contemporary reference to "prior restraint" as if that phrase, without more, were a term of settled content. Thus, assertions that prior restraints are particularly disfavored or that they have thus-and-so characteristics are often made without specifying exactly what situation-if any-the speaker has in mind. The tyranny of labels is such that all things called by the same name are assumed to have the same features, even where the label has been used for reasons other than descriptive accuracy. As a result, there is a tendency to ascribe to one of the several manifestations of "prior restraint" a line of reasoning applicable only to another and thus to confuse rather than to clarify the underlying questions of First Amendment policy.

An obvious solution to this problem is to redefine the concept, to restrict the frame of reference to a set of structurally similar situations about which doctrinal generalizations can usefully be made. This is the goal of the many books and articles that undertake to define what constitutes a prior restraint. The best of these efforts look at the problem in reverse-that is, they begin with the functional consequence of finding a prior restraint and then seek to identify characteristics that justify that result. In other words, the scholarship seeks a functional reconstruction of prior restraint in terms that link the definition of the category with the

38. Emerson recognized this point and explicitly linked the doctrine of prior restraint to a strong cormmitment to First Amendment freedoms:

As a starting point, one must assume the general principle that, under the First Amendment and our notions of a democratic society, freedom of expression is the rule and constraint the exception. . . . [The] principle, that only in the most urgent circumstances can a limitation upon freedom of expression be justified, and that the courts, under the First Amendment, have a serious obligation to strike down limitations which do not clearly meet such conditions, is fundamental to any analysis of prior restraint.

Emerson, supra note 11, at 655 . 
rationale for creating a rule of independent constitutional disfavor.

Perhaps the most influential of these efforts is the classic article by Thomas Emerson. Professor Emerson proposed a four-part typology of prior restraint. ${ }^{39}$ The first two categories correspond to the permit and injunction cases described above. For Emerson, the "clearest form of prior restraint arises in those situations where the government limitation . . . undertakes to prevent future publication or other communication without advance approval of an executive official." ${ }^{\prime 40}$ For convenience, this may be called a scheme of licensing or administrative preclearance. Emerson's second category includes injunctions and related judicial processes enforced through contempt proceedings. The third category consists of what might be called legislative prior restraints-statutes "which make unlawful publication or other communication unless there has been previous compliance with specific conditions imposed by legislative act."11 The fourth type of prior restraint is a residual category loosely described as encompassing indirect or secondary forms of prior restraint.

Emerson acknowledges that neither of the last two categories justifies the strict rule against prior restraint and suggests that the review of such restrictions more or less be assimilated to the appropriate standards for determining the constitutionality of subsequent punishment. As to the first two categories, however, Emerson's objective is to affirm the basic soundness of the rule against prior restraint-a rule that he defends as "not simply an arbitrary historical accident, but a rational principle of fundamental weight in the application of the First Amendment."12

My disagreement with this approach is limited, but not insignificant. Attention to the first two categories of Emerson's typology will reveal both the common ground and the point of departure.

\section{A. Administrative Preclearance}

Of the various things referred to as prior restraint, a system of administrative preclearance is the most plainly objectionable. Under such a system, the lawfulness of speech or publication is made to depend on the prior permission of an executive official. Ordinarily, publication without such permission is punished as a criminal offense, even where the particular speech in question could not constitutionally have been suppressed. Thus, it is the failure to obtain preclearance rather than the character of

39. Id. at 655-56.

40. Id. at 655 .

41. Id. at 656 .

42. Id. at 660 . A more modest but essentially compatible conclusion was reached by Professor Blasi, who examined the collection of licensing and injunction cases under the rubric of "prior restraint" and found the concept "coherent at the core." Blasi, supra note 13, at 93. 
the speech itself that determines illegality.

Such a scheme has many vices. ${ }^{43}$ The administrative apparatus erected to effect preclearance may screen a range of expression far broader than that which otherwise would be brought to official attention. The relative ease and economy of an administrative decision to suppress may make suppression more likely than it would be without a preclearance requirement. Under a system of administrative preclearance, suppression is accomplished "by a single stroke of the pen." At that point the burden falls on the would-be speaker to vindicate his right. Without administrative preclearance, the government's decision to suppress may be constrained by the time and money required to demonstrate in court an appropriate basis for such action. And the fact that those exercising the authority of preclearance operate in the relative informality of administrative action may tend to shield their decisions from effective public scrutiny. Most important, administrative preclearance requires a bureaucracy of censorship. Persons who choose to fill this role may well have psychological tendencies to overstate the need for suppression. Whether or not this is so, there are powerful institutional pressures to justify one's job, and ultimately one's own importance, by exaggerating the evils which suppression seeks to avoid. As Emerson put it: "The function of the censor is to censor. He has a professional interest in finding things to suppress." ${ }^{\text {"44 }}$ And finally, it may well be that a system of administrative preclearance would be enforced more energetically and efficiently than a system of subsequent punishment. Ultimately, both depend on criminal prosecution, but the issues presented for proof under a preclearance requirement may be significantly more manageable. ${ }^{45}$

These and similar arguments have been detailed by Professor Emerson. They deal with matters of timing, process, and institutional structure rather than with the substantive content of speech, and in my view, they

43. At least they are "vices" if one assumes, as I do, that government suppression of speech should be very much the exception rather than the rule. In another frame of reference, characteristics of administrative preclearance that enhance the efficiency of suppression might be seen as virtues. Of course, the assumption that legitimate government suppression of speech is exceptional does not mean, as absolutist rhetoric sometimes suggests, that suppression is never legitimate.

44. Emerson, supra note 11, at 659 .

45. These remarks are based on Emerson's analysis but do not do justice to the detail with which his position is developed. See Emerson, supra note 11, at 656-60. To the same effect, see Mayton, supra note 13 , at $250-52$.

For the suggestion that judges are really no better than bureaucrats in the administration of the First Amendment, see Hunter, Toward a Better Understanding of the Prior Restraint Doctrine: $A$ Reply to Professor Mayton, 67 CORNELL L. REV. 283 (1982). This is a matter of intuition and judgment, but in my view Professor Hunter glides too easily from the indisputably correct observation that judges are not infallible to the radically different proposition that they are therefore no better than professional censors. For my part, I think they are better, and significantly so, in administering a system of freedom of speech. See also infra note 54 (related comment by Professor Monaghan); note 57 (discussing "insensitivity" of judges to First Amendment issues). 
fully justify an attitude of special hostility toward preclearance requirements. All of these concerns, however, are linked to a single factor, a factor ordinarily determinative of the constitutional fate of preclearance requirements. That factor is discretion. Where broad discretion is left in the hands of executive officials - as in a statute authorizing denial of a permit for very general reasons - the vices described above loom very large indeed. Where, on the other hand, executive discretion is tightly controlled-as in a statute requiring issuance of a permit on specified showings-the problems of preclearance seem relatively less troublesome.

The dangers of discretion have been emphasized repeatedly by the Supreme Court. Virtually all of the permit decisions noted earlier identify unconstrained executive discretion over speech and related activities as the chief reason for invalidation. The lesson of numerous older decisions was summarized in Niemotko v. Maryland, ${ }^{48}$ in which the Court said:

In those cases this Court condemned statutes and ordinances which required that permits be obtained from local officials as a prerequisite to the use of public places, on the grounds that a license requirement constituted a prior restraint on freedom of speech, press and religion, and, in the absence of narrowly drawn, reasonable and defnite standards for the officials to follow, must be invalid..7

To the same effect is Shuttlesworth v. City of Birmingham, ${ }^{48}$ in which the Court struck down a law authorizing denial of a parade permit whenever city officials thought that "the public welfare, peace, safety, health, decency, good order, morals or convenience require that it be refused."49 The Court found this law defective in its failure to provide "narrow, objective, and definite standards to guide the licensing authority." when such standards are provided (assuming, of course, that they are substantively consistent with the First Amendment), parade permit laws and other kinds of nondiscretionary licensing requirements are routinely upheld. $^{.1}$

But what if the criteria for suppression resist narrow, precise, and objective formulation? What if the standard is so general, so vague, or so dependent on questions of degree that substantial discretion inevitably at-

46. 340 U.S. 268 (1951).

47. Id. at 271 (emphasis added).

48. 394 U.S. 147 (1969).

49. Id. at $149-50$.

50. Id. at 151 .

51. See, e.g., Heffron v. International Soc'y for Krishna Consciousness, Inc. 452 U.S. 640 (1981) (upholding rule restricting distribution, sales, and solicitation activities to fixed location at fair); Cox v. New Hampshire, 312 U.S. 569 (1941) (upholding content-neutral time, place, and manner restrictions on religious parade). 
tends its application to particular facts? Obscenity is the classic case. The Supreme Court has held (rightly or wrongly) that obscenity is not protected speech, but it has never succeeded in defining that concept in narrow, precise, and objective terms. ${ }^{52}$ No matter how closely an administrator is tied to the constitutional definition of obscenity, the determination that something is obscene necessarily involves judgment and evaluation-in short, the exercise of discretion by an executive official. Where executive discretion cannot effectively be constrained by precise standards for decision, the Court has required that its exercise be closely supervised by judicial authority. The leading decision is Freedman v. Maryland ${ }^{53}$ in which the Court ruled that obscenity could be suppressed under a system requiring administrative preclearance of books and magazines, if certain procedures were enforced to ensure effective judicial supervision. Specifically, the Court insisted that the censor be required either to issue a license or go to court within a brief time after submission, that no final restraint be imposed absent a judicial determination of obscenity, ${ }^{84}$ that the judicial proceeding be held either before or immediately after denial of a license, and that the burden of establishing a constitutionally acceptable basis for suppression be borne by the censor.

Interestingly, neither of these strategies-eliminating executive discretion by specific standards or controlling it by judicial supervision-is much informed by, or even adequately described by, the traditional doctrine of prior restraint. The doctrine says that administrative preclearance of expressive activities is to be specially disfavored. But it does not say which preclearance schemes should be upheld and which struck down. It does not identify discretion as the crucial factor, nor does it easily accommodate either of the Court's strategies for dealing with that problem. The point here is not that the doctrine of prior restraint works any particular

52. To many, the impossibility of defining obscenity with precision is sufficient reason to hold unconstitutional all laws punishing obscenity as such. The Supreme Court, however, has not taken this view. See Miller v. California, 413 U.S. 15 (1973); Roth v. United States, 354 U.S. 476 (1957).

53. 380 U.S. 51 (1965).

54. Monaghan offers an explication of the Freedman Court's insistence on judicial determination of obscenity:

Freedman's preference for judicial evaluation of first amendment claims rests upon the most fundamental considerations - the inherent institutional differences between courts and administrative agencies . . . . First, long judicial tenure frees judges, in most cases, from direct political pressures. Judicial insulation encourages impartial decisionmaking; more importantly, it permits the courts to take the "long view" of issues. Administrative bodies, particularly at a state level, are rarely so insulated; indeed, they are often seen primarily as political organs. Second, the role of the administrator is not that of the impartial adjudicator but that of the expert-a role which necessarily gives an administrative agency a narrow and restricted viewpoint. . . . Courts, on the other hand, do not suffer congenitally from this myopia; their general jurisdiction gives them a broad perspective which no agency can have. They deal daily with a wide variety of situations, and this fact goes far toward eliminating the deficiencies that come from excessive singlemindedness.

Monaghan, First Amendment "Due Process," 83 HARV. L. REV. 518, $522-23$ (1970). 
mischief (at least not within this context), but only that it is not very helpful.

Mislabeling aside, these cases seem entirely correct. Bureaucratic discretion to control the content of speech is intolerable. Laws that vest such discretion in executive officials should be struck down, even where the discretion has been properly exercised on the facts at hand. The evil of broad preclearance requirements is not limited to the occasional case where the illegality of suppression is fully litigated. It also extends to cases that never reach the courts. The operation of the preclearance requirement will suppress or inhibit speech in situations that judges never see. Laws that create a pervasive risk of unconstitutional suppression of protected speech should therefore be invalidated, even where the risk is not immediately realized, as a prophylaxis against the harm that will be done elsewhere.

This, of course, is a familiar argument. It goes under the name of the overbreadth doctrine. People disagree about details, but few would doubt that the overbreadth doctrine states a centrally important proposition for judicial administration of freedom of speech. In my view, it provides a more informative frame of reference for examining preclearance requirements than does the invocation of prior restraint.

Simply put, the doctrine asserts that an overbroad regulation of speech or publication may be subject to facial review and invalidation, even though its application in the instant case is constitutionally unobjectionable. Thus, a person whose activity could validly be suppressed under a more narrowly drawn law is allowed to challenge an overbroad law because of its application to others. The bare possibility of unconstitutional application is not enough; the law is unconstitutionally overbroad only if it reaches substantially beyond the permissible scope of legislative regulation. Thus, the issue under the overbreadth doctrine is whether a government restriction of speech that is arguably valid as applied to the case at hand should nevertheless be invalidated to avoid the substantial prospect of unconstitutional application elsewhere.

A rule of special hostility to administrative preclearance is just another way of saying that determinations under the overbreadth doctrine should take account not only of the substance of the law but also of the structure of its administration. The reason that the various features of timing, process, and institutional structure noted earlier are thought to render administrative preclearance requirements especially objectionable is precisely that they increase the prospect of unconstitutional application. Put another way, a system of administrative preclearance is likely to render a 
restriction of speech operatively, if not formally, overbroad. ${ }^{\mathrm{ss}}$ Narrow, precise, and objective standards are one way of constraining discretion; subjecting its exercise to judicial supervision is another. In either event, the goal is to limit the opportunities for unconstitutional suppression of protected speech, regardless of whether that danger arises from an overly broad statement of the substantive standard for suppression or whether it flows from the overly broad administration typical of a preclearance requirement.

\section{B. Injunctions}

The second major type of prior restraint is the injunction. Ever since Near, injunctions have been classed as prior restraints and subjected to the independent presumption of unconstitutionality for which that doctrine calls. In fact, despite its original reference to official licensing, the doctrine of prior restraint today is understood by many people to mean chiefly a rule of special hostility to injunctions. ${ }^{36}$ Of course, to the extent that the speech in question is constitutionally protected against suppression by subsequent punishment, it is also secured against suppression by injunction. This result in no way depends on an independent rule against prior restraint. That doctrine has functional significance only where it bars an injunction against speech that constitutionally could be proscribed by the penal law. The issue, therefore, is whether injunctions should be constitutionally disfavored even where they are directed against speech not otherwise protected under the First Amendment.

In this connection, it is instructive to note how different from administrative preclearance injunctions really are. Under a regime of injunctions, there is no routine screening of speech and no administrative shortcut to suppression. The government has to shoulder the entire burden of identifying the case for suppression and of demonstrating in court a constitutionally acceptable basis for such action. Moreover, because an injunction must be sought in open court, the character of the government's claims remains subject to public scrutiny and debate. Most important, the decision to suppress is made by a court, not a censor. Of course, judges are not perfect; sometimes they may err on the side of suppression and enjoin speech without sufficient justification. But the fact remains that judges,

55. Professor Tribe makes much the same point in his discussion of "The Problem of Overbroad Delegation" and "Procedural Overbreadth." See L. TRIBE, AMERICAN CONSTITUTIONAL LAW §§ 1235, $12-36$ (1978).

56. See, e.g., Smith v. Daily Mail Publishing Co., 443 U.S. 97, 103 (1979) (where, in referring to Oklahoma Publishing Co. v. District Court, 430 U.S. 308 (1977), a pretrial order enjoining publication of name or photograph of 11-year-old boy charged with juvenile delinquency is condemned as "a classic prior restraint"); Blasi, supra note 13, at 15 (injunctions are "the core of the prior restraint doctrine"). 
unlike professional censors, have no vested interest in the suppression of speech. The institution of the judiciary is peculiarly well suited-in personnel, training, ideology, and institutional structure-to implement the ideals of the First Amendment. ${ }^{67}$ Indeed, it seems especially noteworthy in this regard that Freedman v. Maryland sought to control the vices of administrative preclearance by superimposing on that scheme a requirement of procedure by injunction. This decision is eloquent testimony to the structural dissimilarity of these two mechanisms of suppression and of their differential compatibility with our system of freedom of speech. ${ }^{88}$

Not only are injunctions unlike administrative preclearance, they are also far more like subsequent punishments than the conventional rhetoric would suggest. In both cases the threat of punishment comes before publication; in both cases the fact of punishment comes after. The apparent distinction in timing is actually only a shift in the focus of attention. The procedures in an action for criminal contempt-the enforcement phase of the injunctive process-are generally the same as those used in ordinary

57. Distrust of judges is a central and recurring theme in the writings of those who endorse the conventional doctrine of prior restraint. An articulate and sophisticated rendition of this sentiment appears in Blasi, supra note 13, at 52-53. Professor Blasi advances the notion that "judges tend to be unduly risk averse in ruling upon the claims of speakers" and notes the role of that idea in the works of Chafee, Kalven, and Emerson and in the opinions of Justices Holmes and Brandeis. Id. at 52. From this, Blasi concludes that "a preference for the dynamics of subsequent punishment"-in particular, adjudication of the dangers of speech only after the harm has been realized-_makes sense" as a counterweight to chronic judicial risk-aversion in the regulation of controversial speech. Id.

There is something to this point, but it is not, I think, a persuasive justification for maintaining the doctrine of prior restraint. Two considerations seem to me to support a different view. The first I hesitate to state, as it is both impressionistic and sure to elicit disagreement, but I confess to some doubt that the judiciary of today should be characterized as chronically or pervasively insensitive to First Amendment interests. It is worth remembering that the judicial attitudes criticized by Chafee, Holmes, and Brandeis, and to a considerable extent by Kalven and Emerson, were those of a different generation. It seems to me that with every passing decade-not excluding the 1970s and the advent of the Burger Court-there is increasingly widespread acceptance of First Amendment claims that would have been thought fanciful only a few years earlier. That is not to say, of course, that the judges have kept up with their critics, or indeed that they shall ever do so, but only that judicial attitudes of the thirties, forties, and fifties, which in retrospect seem distinctly inhospitable to First Amendment interests, should not lightly be assumed to have continued until today.

The second point is more fundamental. To the extent that the judges of today can be thought, by whatever lights, chronically and pervasively insensitive to First Amendment interests, there is clearly a serious problem. But it is less clear that this problem can sensibly be addressed through a particularized hostility to injunctive relief. After all, the same judges will adjudicate the substantive content of First Amendment freedoms no matter what the form of government regulation. A generally inhospitable attitude would seem likely to affect actions to impose subsequent punishment as well as proceedings for injunctive relief. In order to make a case for a rule of special hostility to injunctions, one must go further and argue, as Professor Blasi suggests, that judges are differentially insensitive to First Amendment interests depending on the form of enforcement sought. On this crucial point the argument is quite speculative. In sum, therefore, it seems to me unlikely that a sharp distinction between injunctions and subsequent punishment can be supported by plausible assumptions about judicial behavior.

58. For a more detailed explication of the functional dissimilarities of licensing and injunctions, see Mayton, supra note 13, at 249-53. 
criminal prosecutions. Proof must be had beyond a reasonable doubt, ${ }^{50}$ and the right to trial by jury is guaranteed where the sentence exceeds imprisonment for six months. ${ }^{60}$

On examination, the chief difference between the two schemes turns out to be this: Under a system of injunctions, the adjudication of illegality precedes publication; under a system of criminal prosecution, it comes later. This is a difference, and perhaps for some purposes it matters, but why the timing of the adjudication should affect the scope of First Amendment freedoms is not at all clear. Three related reasons are most frequently advanced.

The first and most common is that an injunction deters speech more effectively than does the threat of criminal prosecution and for that reason should be specially disfavored. Arguments to this effect are found in the opinions of the Supreme Court ${ }^{61}$ and in the writings of leading commentators. ${ }^{62}$ The idea has been variously expressed but never so pithily as in

59. Gompers v. Buck's Stove \& Range Co., 221 U.S. 418, 444 (1911).

60. Bloom v. Illinois, 391 U.S. 194 (1968). The absence of a jury trial where only petty penalties are imposed is a difference, but not, I think, one that counts for much under the First $\Lambda$ mendment. Whatever may have been true in the days of John Peter Zenger, the essentially popular institution of the modern Americal jury seems unlikely to serve as a bulwark of protection for unpopular speech. On this point, 1 am persuaded by the comments in Monaghan, supra note 54, at 526-32. In particular, he writes:

The jury has, it is true, long been extolled as a great guarantor of individual freedom, including freedom of speech. English history and our own colonial past contain notable illustrations of the jury's refusal to return convictions based upon criticism of government. But one should recall that the famous free speech cases of the past were really part of a much larger conflict between a fairly homogeneous citizenry and an unrepresentative government. In earlier times, therefore, freedom of speech was conceived primarily as a guarantee that the voice of the people-the majority-would be heard, that unrepresentative government would be forced to hear, if not heed, their rising voices. As a bearer of majority sentiments, the jury served as a powerful and effective vehicle for preventing governmental repression of majority views. The law of seditious libel found rough sledding in the hands of English and colonial juries. It is, however, important to recognize that the juries were extolled because they were acting in a lawless fashion. They may have helped to create new laws, but as the famous trial of John Peter Zenger illustrates, they plainly refused to abide by the laws they were charged with administering. And when public sentiment ran strongly in favor of the government, juries could readily become ex post facto censors of the press in libel cases.

Id. at 528-29 (footnotes omitted); accord Mayton, supra note 13, at 277.

61. In Nebraska Press Ass'n v. Stuart, 427 U.S. 539 (1976), the Court stated:

A criminal penalty or a judgment in a defamation case is subject to the whole panoply of protections afforded by deferring the impact of the judgment until all avenues of appellate review have been exhausted. . . .

A prior restraint, by contrast and definition, has an immediate and irreversible sanction. If it can be said that a threat of criminal or civil sanctions after publication "chills" speech, prior restraint "freezes" it at least for the time.

Id. at 559 (footnote omitted).

62. For example, Professor Tribe writes that:

[I] $t$ might well [be] the case that pre-publication restraints, especially those affirmatively singling out the would-be disseminator, would deter far more protected conduct than criminal statutes ordinarily would. The latter is essentially a mute, impersonal threat; being told personally not to publish is apt to cause more second thoughts-no matter what defenses are ultimately available. 
Alexander Bickel's remark that, "A criminal statute chills, prior restraint freezes." ${ }^{\text {"Bs }}$ Yet, with all respect to such authority, it is very hard to credit this point. It may be true, as many have asserted, that an injunction, because it is particularized, immediate, and concrete, may impinge more forcefully on the consciousness of the individual enjoined than would a more generalized and impersonal threat of criminal prosecution. But that tells only half the story, and the wrong half at that. An injunction may be more effective at stopping the activity at which it is aimed, but it is also more narrowly confined. There is less risk of deterring activities beyond the adjudicated target of suppression-activities plainly outside the injunctive ban but arguably within the necessarily more general prohibition of a penal law. And many find even an uncertain prospect of criminal conviction and punishment sufficient incentive to steer well clear of arguably proscribed activities. In terms, therefore, of the system of free expression and of the aggregate of arguably protected First Amendment activity that might be inhibited under these regimes, it is anything but clear that injunctions are more costly. As Professor Barnett put it: "[T]he pinpointed freeze of a narrowly drawn [judicial] . . . order might produce less refrigeration overall than the broader chill of threatened subsequent punishment ...."

That point is strongly reinforced when one remembers that it is only the possibility of erroneous deterrence that should be the subject of concern. To the extent that the activity suppressed, whether by injunction or by criminal prosecution, is outside the protection of the First Amendment and within a legitimate sphere of legislative action, efficient inhibition is a good thing. It is only excessive deterrence, erroneous deterrence, deterrence that impinges on the substance of First Amendment freedoms, that is to be decried. In that respect, it seems entirely plausible that the specifically targeted commands of an injunction are actually likely to be less threatening to the system of freedom of expression than the inevitably more general proscriptions of a penal statute. ${ }^{85}$

Two additional reasons for regarding injunctions as especially deleterious to speech are really only variations on the theme of efficient deterrence. One is that suppression by criminal prosecution is preferable to suppression by injunction because the latter characteristically delays publication, at least for several days, even if the ban ultimately is lifted. The result is a loss in the immediacy of speech, and in some cases an accompa-

L. TRIBE, supra note $55, \S 12-32$, at 726 n.2.

63. A. BICKEL, THE MORALITY OF CONSENT 61 (1975).

64. Barnett, supra note 13 , at 551 .

65. It was the inevitable generality of penal statutes that led Professor Mayton to describe subsequent punishment, rather than prior restraint, as "uniquely injurious" to freedom of speech. Mayton, supra note 13, at 254 . 
nying loss in its value. The other contention is that criminal prosecution is preferable because it allows the disputed material to be published at least once and thus to enter the marketplace of ideas. An injunction, by contrast, is said to prevent the information from ever being made public.

Both of these contentions enjoy wide currency, ${ }^{66}$ but neither withstands scrutiny. Both are based on the implicit assumption that the deterrent impact of penal statutes is felt in those cases in which prosecution is brought. Of course, the opposite is true. Every violation of the penal law is, by hypothesis, a case of failed deterrence. Effective deterrence occurs when the violation never takes place. And in some cases, deterrence will be effective. Thus, while an injunction may delay publication for several days, the prospect of penal sanctions may delay publication forever. And while those publications that become subjects of criminal prosecution do become part of the marketplace of ideas, those that are deterred by the threat of penal sanctions never do. There is, in short, no necessary or dependable relation between the form of suppression and any identifiable measure of violence to First Amendment interests. ${ }^{67}$

66. See, e.g., L. TRIBE, supra note 55, $\$ 12-31$; Developments in the Law-The National Security Interest and Civil Liberties, 85 HARV. L. REV. 1130, 1240-41 (1972).

67. Arguments of a different sort are advanced in Blasi, supra note 13. Professor Blasi examines licensing and injunctions in an effort to assess whether the two modes of regulation are sufficiently similar to warrant lumping them together under the rubric of "prior restraint." He concludes that they are and accordingly pronounces the concept "coherent at the core." Id. at 93. Blasi, however, does not base his conclusion on the usual contention that licensing and injunctions are alike in producing significantly more self-censorship of speech than do schemes of subsequent punishment. In fact, he specifically disavows that view. Id. at 47 . Instead, he suggests that a rule of special hostility to injunctions is justified by the common tendencies of licensing and injunctions to allow speculative assessments of the dangers of speech (the problem of "adjudication in the abstract"), to invite overuse by enforcement authorities, and to dilute the impact of speech on the audience to whom it is addressed.

Professor Blasi's analysis of these factors is both thoughtful and thought-provoking. It is also far too elaborate and detailed for point-by-point response. In my view, the strongest of these arguments goes under the heading of "adjudication in the abstract." See id. at 49-54. The crux of this discussion is an assumption of chronic judicial risk-aversion, and I have suggested elsewhere why that seems to me an unconvincing justification for the doctrine of prior restraint. See supra note 57.

Blasi's arguments on overuse, Blasi, supra note 13, at 54-63, and impact on audience reception, id. at 63-69, are developed with great care and subtlety. They also reflect the inevitable difficulties of drawing very specific inferences about relative impact from necessarily abstract speculations about the differences among legal regimes. Thus, for example, a key to Blasi's analysis of overuse as a ground for disfavoring prior restraints is the observation that injunctions are easier to obtain than penal statutes. See id. at 58. This may be true, but it is equally true that a criminal statute, once enacted, is likely to have a vastly greater longevity and breadth of potential application. It may be, therefore, that the better comparison is not between the relative ease of obtaining an injunction and the greater difficulty of enacting legislation but rather between the streamlined procedures for obtaining an injunction and the even more expeditious and informal procedures by which a prosecutor may threaten or initiate criminal prosecution. My point here is not to suggest that an inquiry into potential for overuse would actually favor injunctive regulation over criminal prosecution, or even that the contrary perception is necessarily in error. My only point is to express doubt that any inference of this sort can reliably be drawn.

In many ways the most interesting aspect of Blasi's argument is the suggestion that injunctions and subsequent punishments are differentially incompatible with the underlying premises of the American constitutional scheme. This is not an argument based on predictions of behavioral consequences. It 
In my view, there is only one respect in which injunctions plausibly can be claimed to have a First Amendment impact significantly greater than the threat of subsequent punishment. That argument is based on the traditional rule that the legality of an injunction may not be challenged by disobeying its terms. ${ }^{68}$ In its most uncompromising form, the traditional approach would declare that the invalidity or even unconstitutionality of a court order would be no defense in a contempt proceeding based on violation of that order. An especially rigorous application of this rule is found in Walker v. City of Birmingham, ${ }^{69}$ where the Supreme Court upheld contempt convictions for violating a court order against parading without a permit, despite the fact that the injunction tracked the language of a city ordinance later found to have been an unconstitutional restraint on free expression. ${ }^{70}$ The right course, said Walker, was for the demonstrators to challenge the validity of the injunction in court before violating it on the streets. "[R]espect for judicial process," said Justice Stewart, "is a small price to pay for the civilizing hand of law . . .".71

Today, the continued vitality of Walker v. City of Birmingham is far from clear. The Supreme Court has declined to follow that course in analogous situations, and the lower courts have tended to curtail its reach. ${ }^{72}$ Nevertheless, the rule probably survives-at least one cannot confidently

deals rather with matters of symbolism and tone. Much of this argument seems to me properly reflective of a generalized predisposition against governmental suppression of speech by whatever means, and, so understood, I agree with it wholeheartedly. I am less sure, however, that the fundamental concerns that argue against the suppression of speech generally-concerns that Blasi develops with elegance and insight-justify a sharp differentiation between injunctions and subsequent punishments.

Consider, for example, Blasi's analysis of "the premise of distrust." He summarizes his discussion of this point as follows: "[T]he widespread use of licensing or enjoining implies a premise of comparative distrust, a belief that it is more dangerous to trust audiences with controversial communications than it is to trust the legal process with the power to suppress speech." Id. at 85. This observation is both right and important, and I agree with it completely. It seems to me, however, that widespread use of criminal prosecution and punishment would be equally objectionable and for the same reason. Blasi distinguishes the two cases on the ground that "[t] to sanction," id. at 72, and that its use is therefore specially incompatible with a system of freedom of speech. But the point of subsequent punishment is equally to suppress and not to sanction. In neither regime is the penalty an end in itself; in both it is imposed as a means to control primary conduct-specifically to suppress speech. The case for a sharp doctrinal differentiation between injunctions and subsequent punishment-as distinct from the more general (and more important) proposition of a healthy skepticism toward suppression by any means-seems to me unpersuasive.

68. See generally O. FISS, THE CIVIL RIGHTS INJUNCTION 72-74 (1978) (discussing extent to which disobedience of injunction will be detected and prosecuted more rigorously than disobedience of criminal statute); Cox, The Void Order and the Duty to Obey, 16 U. CHI. L. REV. 86 (1948) (examining circumstances in which invalid order or temporary injunction issued by federal court is entitled to obedience); Rendleman, Free Press-Fair Trial: Review of Silence Orders, 52 N.C.L. REV. 127 (1973) (analyzing problems involved in obtaining appellate review of silence order issued in criminal proceeding); Rendleman, More on Void Orders, 7 GA. L. REV. 246 (1973) (discussing allegedly unconstitutional operation of collateral bar rule with respect to ex parte injunctions).

69. 388 U.S. 307 (1967).

70. Shuttlesworth v. City of Birmingham, 394 U.S. 147 (1969).

71. 388 U.S. at 321 .

72. See Blasi, supra note 13 , at 20-22 (sources cited therein). 
say otherwise-and thus must be taken into account. For whatever uncertainty may attend the current health of the collateral bar doctrine, its relevance to prior restraint is plain. If Walker were strictly followed and if immediate appellate review of judicial orders were not provided, the government might be able temporarily to suppress by injunction speech that could not be suppressed by threat of penal sanctions. That is because persons enjoined from publication would have to forego such action, at least temporarily, in order to preserve their constitutional claims. No such forebearance would be required under a system of subsequent punishment, at least if the individual involved were sufficiently sure of success on the merits or sufficiently brave to take the risk. Of course, it is an important safeguard against such abuse that the order must be issued by a judge, not a bureaucrat, but the possibility of judicial error or insensitivity to First Amendment freedoms is not so trivial that it may safely be ignored.

Other writers-notably Professors Fiss and Barnett ${ }^{73}$ - have examined the rule of Walker v. City of Birmingham and noted its centrality to any convincing rationalization of the doctrine of prior restraint. They have argued that a policy of special hostility to injunctions is at least unjustified where the collateral bar rule is not in force. As should be clear from what has already been said, I agree with this view. Indeed, I would go further, for it seems to me that a properly limited collateral bar rule would not be destructive of our system of freedom of expression.

The reasons for the collateral bar rule are obvious and not unimportant. They include the preservation of judicial authority and the orderly settlement of disputes-values evoked by Justice Stewart's reference to "the civilizing hand of law." But it is also clear that, at least in the context of injunctions against speech, the collateral bar rule must be carefully circumscribed. The Supreme Court has recognized the point and limited the rule accordingly. Indeed, in Walker itself the Court acknowledged that a different situation would be presented if an injunction were "transparently invalid" or if delay or frustration were encountered in the effort to contest its validity. ${ }^{\mathbf{7 4}}$

The first of these exceptions covers the case of an injunction so palpably contrary to authority that it falls under a kind of "plain error" rule. The limitation is not trivial, for existing First Amendment precedents would render "transparently invalid" a vast range of injunctions against speech. Nevertheless, this formulation does not address the truly close case, however occasionally it may arise. The second exception may be more to the

73. See O. FISS, supra note 68 , at 30 ; Barnett, supra note 13 , at 553-54.

74. 388 U.S. at $315,318$. 
point, for it speaks directly to the central problem of the collateral bar rule-the risk that an injunction against speech, even though ultimately invalidated, will so delay publication as to make the speech untimely and hence valueless for its purpose. The worst case would be an election-eve attempt by the party in power to enjoin publication of politically damaging information. In such circumstances, even the few days necessary to obtain expedited appellate review might prove seriously prejudicial to that system of representative government which the First Amendment, above all else, should be thought to undergird ${ }^{75}$ In my view, therefore, the normal operation of the collateral bar rule can be sustained only so long as expedited appellate review allows an immediate opportunity to test the validity of an injunction against speech and only so long as that opportunity is genuinely effective to allow timely publication should the injunction ultimately be adjudged invalid. In any event, this is, as Professor Blasi put it, only a "controversy over the validity and scope of the collateral bar rule." view, as a remote and usually unarticulated premise underlying a broad and uncritical acceptance of the conventional rhetoric of prior restraint.

The conclusion that I draw from all this is embarrassingly modest. It is not that injunctions are preferable to subsequent punishment as a mechanism for suppression of speech, though that may be true in some cases. Nor would I assert that there is never a case in which injunctive relief should be specially disfavored. In some situations (the election-eve gambit comes to mind) an injunction may be differentially destructive of First Amendment values, just as in others (perhaps regulation of obscenity) it may prove differentially protective. My only point is to question the broad and categorical condemnation of injunctions as a form of "prior restraint."

In my view, a rule of special hostility to administrative preclearance is fully justified, but a rule of special hostility to injunctive relief is not. Lumping both together under the name of "prior restraint" obscures rather than clarifies what is at stake in these cases. In the context of administrative preclearance, talking of prior restraint is unhelpful, though not inapt. A more informative frame of reference would be overbreadth, the doctrine that explicitly identifies why preclearance is specially objectionable. In the context of injunctions, however, the traditional doctrine of prior restraint is not merely unhelpful, but positively misleading. It focuses on a constitutionally inconsequential consideration of form and diverts attention away from the critical substantive issues of First Amend-

75. Of course, there are other values that the First Amendment might plausibly be thought to protect. I do not mean to reject such additional values, but only to identify what seems to me centrally at issue in this context.

76. Blasi, supra note 13 , at 22 . 
ment coverage. The result is a two-pronged danger. On the one hand, vindication of First Amendment freedoms in the name of prior restraint may exaggerate the legitimate reach of official competence to suppress by subsequent punishment. ${ }^{77}$ On the other hand, insistence on special disfavor for prior restraints outside the realm of substantive protection under the First Amendment may deny to the government an appropriate choice of means to vindicate legitimate interests. In my view, neither risk is justified by any compelling reason to continue prior restraint as a doctrinally independent category of contemporary First Amendment analysis.

III.

The burden of the preceding discussion is to suggest that the conventional doctrine of prior restraint should be retired from active service in First Amendment adjudication. Its historic role in protecting freedom of expression has been superseded by the expanded substantive coverage of the First Amendment and by the development of other, and more apt, techniques for implementing that guarantee. Moreover, continuing uncertainty as to what is actually meant by "prior restraint" and the accelerating tendency to invoke that phrase in a wide variety of dissimilar cases have undermined whatever usefulness the doctrine may have had in explaining or predicting results. Most regrettable of all is the demonstrated potential of the words "prior restraint" to confound and deflect rather than to guide and clarify the analysis of important questions of First Amendment policy.

It may help flesh out this conclusion if I trace its implications for the testing case of national security. To that end, abstracts of three kinds of conflicts between the First Amendment and national security are sketched out below. "Sketched out" is used advisedly, for I make no pretense of probing the depths of the conflict between national security and freedom of speech. My purpose here is chiefly to trace out in a particular context the implications of the preceding discussion of the prior restraint doctrine and only incidentally to address specific issues of the legal regulation of national security. The following comments are, therefore, brief and tentative.

The first and most obvious legal regime in aid of national security would be an Official Secrets Act. The United States is unusual, even among Western democracies, in its refusal to adopt legislation of this sort. An Official Secrets Act presumably would be based on some administrative apparatus for declaring official secrets-perhaps on something similar

77. This concern is voiced in Fiss, Free Speech and the Prior Restraint Doctrine: The Pentagon Papers Case, in The Supreme CourT AND HuMAN RIGHTS 49, 60-61 (B. Marshall ed. 1982). 
to the present system for classification of information relevant to defense, security, or foreign policy. A comprehensive protection against disclosure of such information could be erected by appending to the classification system a criminal provision against unauthorized publication or disclosure of classified material. Such a requirement would go a long way toward enabling our government to safeguard the lives and resources secrecy protects, as well as to encourage the kinds of intergovernmental and private collaborations that have secrecy as a prerequisite.

In my view, such a system might also go a long way toward eviscerating the First Amendment and frustrating our national commitment to government by the people. A broad Official Secrets Act would embody all the worst and most dangerous features of administrative preclearance. There would be every reason to expect that the executive officials charged with the duty of classification would systematically overuse that authority to the detriment of political freedom and representative democracy. There would be the bureaucrat's usual incentive to exaggerate the significance of his own responsibilities by assigning high security classifications to what he reviews; the expert's predictable bias toward overemphasizing the considerations that flow from that expertise; the government official's understandable tendency to discount the broader societal interest in controlling government; and the executive officer's inevitable temptation to suppress information that might prove embarrassing or damaging to his conception of the national interest. There would, in short, be an inherent proclivity toward pervasive and uncontrollable overbreadth in the classification of official secrets. In my view, therefore, such a scheme should be judged facially unconstitutional under the First Amendment, even if its application in a particular case could be supported by demonstration of a legitimate government interest.

A second and more difficult issue is presented by the enforcement of government employee secrecy agreements. The constitutionality of a secrecy agreement used by the Central Intelligence Agency (GIA) was upheld by a divided Court in Snepp v. United States, ${ }^{78}$ but that decision has served only to arouse rather than to resolve controversy. In that case, the CIA required that Frank Snepp sign, as a condition of his employment, a standard secrecy agreement requiring that he not publish material about the Agency, its activities, or intelligence gathering generally without prior approval. From one point of view, this looks like a classic case of administrative preclearance. Material had to be submitted to a government official who made an ex parte determination of the legality of publication. Failure to obtain preclearance was a breach of the government's rights under the

78. 444 U.S. 507 (1980) (per curiam). 
agreement even if, as was conceded for the purpose of litigation in Snepp, the publication contained no material that could lawfully have been suppressed. No judicial supervision was required, nor was there any demonstration of a compelling governmental interest supporting suppression.

The trouble is that this analysis rings true only if one starts from the position that Snepp has information and wants to publish it. In that frame of reference, the content of the government's action is a restraint on publication, and the form of the restriction is administrative preclearance. There is, however, an alternative starting point. One could begin with the earlier state of affairs where Snepp does not have information but wants to get it. ${ }^{78}$ In this view, the issue is not censorship but access to information. The government does not seek to restrain Snepp from publishing what he knows but only to impose conditions on his receipt of government secrets. From this perspective, it is critical that the government has no constitutional obligation to tell Snepp anything. Correlatively, he has no constitutional right to demand access to Agency secrets, either for himself or for the public generally. ${ }^{80}$ Instead, he must bargain to secure whatever access he can on whatever terms the government may require. The resulting secrecy agreement is, therefore, properly viewed not as a governmental infringement of the liberties of the citizen but only as an employer's vindication of the terms of a contract.

There are, of course, other and more sophisticated arguments to be made about $S$ nepp ${ }^{81}$ but, at the bottom, the issue seems to me one of pattern recognition. Is it more natural (in the sense of more consistent with the broader landscape of constitutional restrictions on government) to regard the secrecy agreement as a governmental restraint on First Amendment freedoms, despite its limited application to employees who receive government secrets? Or is it more appropriate to view that agreement as a contract between employer and employee, despite the fact that the employer is the government of the United States and the information potentially relevant to the political control of its activities? Personally, I incline toward the view that employee secrecy agreements should generally be

79. It may seem odd to say that Snepp wanted information, since his immediate objective presumably was to get a job. The two are, however, inextricable, since it would be impossible for Snepp to perform his duties as an agent without access to classified information. By seeking employment necessitating access to information, Snepp necessarily sought the information as well.

80. See generally BeVier, An Informed Public, an Informing Press: The Search for a Constitutional Principle, 68 CALIF. L. REV. 482, 517 (1980) ("' $[A]$ judicially enforceable right to know would be inconsistent with the democratic processes envisioned by the Constitution and thus could not be justified by a first amendment principle . . . .").

81. See, e.g., Dworkin, Is the Press Losing the First Amendment?, N.Y. REV. B0oks, Dec. 4, 1980, at 49; Easterbrook, Insider Trading, Secret Agents, Evidentiary Privileges, and the Production of Information, 1981 SUP. CT. REV. 309; Comment, Snepp v. United States: The CIA Secrecy Agreement and the First Amendment, 81 CoLuM. L. REV. 662 (1981). 
enforceable. ${ }^{82}$ In any event-and this is the point I would emphasize-whatever one's judgment on that question, it would seem to me to be substantially unaided by the traditional doctrine of prior restraint. For me, that formulation would resolve the case only if the government's refusal to provide information in the first instance were constitutionally invalid, and that is plainly not the law.

The third and final situation involves a government effort to enjoin publication of information in the hands of the press or some other third party on the ground of a threat to the national security. This, of course, is precisely the situation presented by New York Times Co. v. United States. As has become clear, it is my view that the outcome of such a case should not turn on the form of relief requested. The same result should obtain whether the government seeks to enjoin the New York Times from publishing information or to prosecute it for having done so. Either kind of proceeding poses the fundamental conflict between the ideals of the First Amendment and the demands of national security. Articulating appropriate criteria for resolving that clash is ultimately the responsibility of the Supreme Court. In my view, that issue should be confronted directly and not through the language of prior restraint. There is, in short, no escape from the difficult challenge posed by Justice Blackmun in New York Times: "What is needed here is a weighing, upon properly developed standards, of the broad right of the press to print and of the very narrow right of the Government to prevent." ${ }^{\text {"8s }}$ The difficult process of judicial weighing is, in my view, entirely unaided by reference to the doctrine of prior restraint.

In sum, therefore, I suggest that in confronting these and similar questions the conventional doctrine of prior restraint be laid to one side. In my judgment, that doctrine is so far removed from its historic function, so variously invoked and discrepantly applied, and so often deflective of sound understanding, that it no longer warrants use as an independent category of First Amendment analysis.

82. In this conclusion, I am much influenced by BeVier, supra note 80 .

83. New York Times Co. v. United States, 403 U.S. 713, 761 (1971) (Blackmun, J., dissenting). 